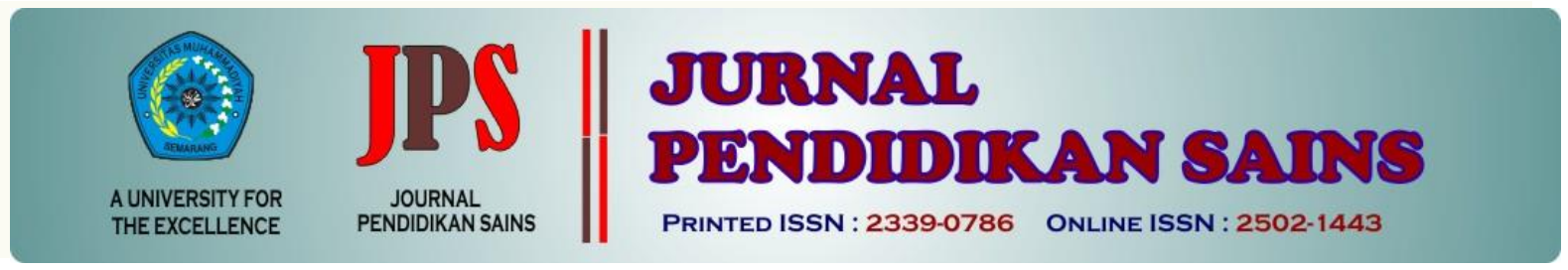

http://jurnal.unimus.ac.id/index.php/JPKIMIA

\title{
KELAYAKAN INSTRUMEN PENGEMBANGAN PENILAIAN HIGHER ORDER THINKING SKILLS SISWA SMA PADA MATERI EKOSISTEM
}

\author{
Oleh: \\ Kusuma Wardany \\ Universitas Nahdlatul Ulama Lampung \\ Email: kusuma.wardany@ymail.com/kusuma.wardany0601@gmail.com
}

\begin{tabular}{ll}
\hline Article history & Abstract \\
\hline $\begin{array}{l}\text { Submission : 2018-09-18 } \\
\text { Revised : } 2018-10-05\end{array}$ & $\begin{array}{l}\text { This study on Higher Order Thinking Skills (HOTS) assessment } \\
\text { employed Borg and Gall (1983)'s modified Research and }\end{array}$ \\
Keyword: & $\begin{array}{l}\text { Development (R\&D). The purpose of this study was to determine the } \\
\text { feasibility of HOTS assessment instruments on ecosystem material. }\end{array}$ \\
Assessment, Higher & $\begin{array}{l}\text { The sample of development included 4 validating experts, 40 students } \\
\text { in limited test, 140 students in field test using Higher Order Thinking }\end{array}$ \\
Order Thinking Skills & $\begin{array}{l}\text { Skills (HOTS) assessment. Data analysis was carried out using Quest } \\
\text { program. The result of research showed that (1) the characteristics of }\end{array}$ \\
(HOTS) & $\begin{array}{l}\text { Higher Order Thinking Skills (HOTS) assessment was developed } \\
\text { based on, among others, Anderson and Krathwohl's indicator of } \\
\text { higher-order thinking skill in ecosystem with validity and reliability } \\
\text { interpreting as having very high mean, at least low in ecosystem } \\
\text { material. The results of the validation of the instrument of assessment } \\
\text { instrument in each expert validator are having a good content and } \\
\text { concept validation to be applied in school, of course after the revision }\end{array}$
\end{tabular}

\section{Pendahuluan}

Pemenuhan standar proses dan standar penilaian merupakan tugas utama guru profesional, agar kualitas pembelajaran dan evaluasi yang dilaksanakan guru dapat ditingkatkan pada jenjang pendidikan menengah (Sajidan dkk, 2013).Standar proses merupakan standar nasional pendidikan yang berkaitan dengan pelaksanaan pembelajaran pada satuan pendidikan untuk mencapai kompetensi lulusan. Standar penilaian merupakan standar nasional pendidikan yang berkaitan dengan mekanisme, prosedur, dan instrumen penilaian hasil belajar peserta didik (BSNP, 2007).

Penelitian Sugiharto \& Prasetyani (2013) menunjukkan bahwa capaian pemenuhan standar proses (standar 2) dan standar penilaian (standar 8) menunjukkan adanya gap yang terbesar antara skor ideal dan skor riil, yaitu sebesar 3,70\%. Hal ini terjadi karena ketercapaian kompetensi pembelajaran di SMA Surakarta melalui aspek kognitif belum dapat meningkatkan Higher Order Thinking Skills siswa (Sajidan, Sugiharto \& Prasetyani, 2013). Permendikbud No. 81 Tahun 2013 tentang implementasi kurikulum menyebutkan bahwa kebutuhan kompetisi masa depan

*Corresponding Author:

$\begin{array}{ll}\text { Nama } & \text { : Kusuma Wardany } \\ \text { Lembaga } & \text { : Universitas Nahdlatul Ulama Lampung } \\ \text { Email } & \text { : kusuma.wardany0601@ gmail.com }\end{array}$


diperlukan Higher Order Thinking Skillssecara kritis, keterampilan komunikasi, dan kreatif(Kemendikbud, 2013). Hal ini sejalan dengan karakteristik skills masyarakat dalam Partnership of $21^{\text {st }}$ Century Skill yang mengidentifikasikan bahwa pebelajar harus mampu mengembangkan keterampilan kompetitif yang berfokus pada pengembangan Higher Order Thinking Skills, seperti : berpikir kritis (critical thinking), pemecahan masalah (problem solving), keterampilan berkomunikasi (communication skills), melek TIK, teknologi informasi dan komunikasi (ICT, information and Communication Technology), melek informasi (information literacy), dan melek media (media literacy) (Basuki \& Haryanto, 2012).

Indikator untuk mengukur Higher Order Thinking Skillsmeliputi keterampilan menganalisa (C4), mengevaluasi (C5), danmenciptakan (C6) (Anderson \& Krathwohl, 2001). Higher Order Thinking Skills sebagai keterampilan berpikir yang terjadi ketika seseorang mengambil informasi baru dan informasi yang sudah tersimpan dalam ingatannya, selanjutnya menghubungkan informasi tersebut dan menyampaikannya untuk mencapai tujuan atau jawaban yang dibutuhkan (Lewis \& Smith, 1993). Higher Order Thinking Skillsdapat dipacu dengan menggunakan modelpembelajaran active learning, yaitu pembelajaran dengan menggunakan Kurikulum 2013 melalui pendekatan saintifik (Hosnan, 2014).

Assesmen atau penilaian merupakan istilah umum yang mencakup keseluruhan prosedur yang digunakan untuk mendapatkan informasi tentang hasil belajar siswa (pengamatan, peringkat, pengujian menggunakan kertas dan pensil) dan membuat penilaian mengenai proses pembelajaran (Gronlund \& Linn, 1995). Evaluasi merupakan suatu proses yang sistematis yang dilaksanakan untuk mengetahui tingkat keberhasilan dan efisiensi dari program. Pengukuran digunakan untuk memperoleh deskripsi numerik atau kuantitatif dalam melakukan tes dan non-tes (Subali, 2010). Higher Order Thinking Skills perlu diukur untuk mendapatkan informasi taraf pengetahuan dan ketrampilan.

Dalam Peraturan Menteri Pendidikan Nasional Nomor 20 Tahun 2007 tentang Standar Penilaian Pendidikan menjelaskan bahwa ulangan adalah proses yang dilakukan untuk mengukur pencapaian kompetensi peserta didik secara berkelanjutan dalam proses pembelajaran, untuk memantau kemajuan, melakukan perbaikan pembelajaran, dan menentukan keberhasilan belajar peserta didik. Menindaklajuti riset yang dilakukan Prof. Dr. rer. nat. Sajidan, M.Si, beserta kawan-kawan, yaitu mengenai kesenjangan gap antara skor ideal dan skor riil di beberapa sekolah SMA di Surakarta, maka dilakukan observasi kembali berkaitan standar penilaian di lima sekolah Surakarta.

Hasil Observasi SMA di Surakarta yang dipilih secara acak, yaitu di SMAN 2, SMAN 3, SMAN 4, SMAN 6, dan SMAN 7 melalui Ulangan dan Ujian seperti Ujian Nasional, Ujian Akhir Semester, Ujian Tengah Semester, Ujian Sekolah, Ulangan Harian, maupun dari buku paket yang guru dan siswa gunakan pada materi ekosistem menunjukkan bahwa soal dan pertanyaan masih dalam ranah kognitif yang rendah (Lower Order Thinking Skills). Rerata presentase pada materi ekosistem di lima sekolah sebanyak 90,5\% Lower Order Thinking Skills, pada ranah kognitif C1 (mengetahui), C2 (memahami), C3 (mengaplikasikan) dan pada dimensi pengetahuan faktual, konseptual dan prosedural, serta hanya 8,4\% Higher Order Thinking Skills, pada ranah C4 (menganalisis), C5 (mengevaluasi) dan pada dimensi pengetahuan faktual dan konseptual.

Hasil rerata presentase pada materi Ekosistem di 5 sekolah sebanyak 81,4\% Lower Order Thinking Skills, pada ranah kognitif C1 (mengetahui), C2 (memahami), C3 (mengaplikasikan) dan pada dimensi pengetahuan faktual, konseptual dan prosedural serta hanya 18,58 \% Higher Order Thinking Skills, baik ranah kognitif C4 (menganalisis) pada dimensi pengetahuan faktual, konseptual dan metakognisi. Soal-soal penilaian di atas diidentifikasikan berdasarkan Taksonomi Bloom yang meliputi dimensi proses berpikir pada dimensi pengetahuan. Dimensi proses berpikir terdiri dari enam kategori, yaitu: $\mathrm{C} 1$ (mengingat), $\quad \mathrm{C} 2 \quad$ (memahami), $\quad \mathrm{C} 3$ (mengaplikasikan), $\mathrm{C} 4$ (menganalisis), $\mathrm{C} 5$ (mengevaluasi), dan C6 (mencipta). Sedangkan pada dimensi pengetahuan, yaitu fakta, konsep, prosedural, dan metakognisis. Ranah C1-C3 merupakan Lower Order Thinking Skills dan C3-C6 merupakan Higher Order Thinking Skills (Anderson \& Krathwohl, 2001).

Rendahnya presentase soal Higher Order Thinking Skillss pada pra eksperimen menjadi indikator rendahnya kognitif siswa di sekolah. Hasil analisis kebutuhan tersebut 
menunjukkan masih terdapat kelemahan pada pemenuhan standar penilaian di sekolah, ini terbukti dengan instrumen penilaian yang digunakan guru di sekolah berdasarkan Taksonomi Bloom masih terkategorikan rendah. Hasil analisis kebutuhan tersebut menunjukkan bahwa guru membutuhkan penilaian yang mampu mengukur Higher Order Thinking Skills.

Penilaian yang mengukur Higher Order Thinking Skills dapat menggunakan bentuk tes subjektif dan tes objektif. Tes subjektif merupakan tes bentuk esai. Alat tes yang baik harus memenuhi sejumlah kriteria, antara lain bahwa tes haruslah tidak terlalu mudah dan sebaliknya tidak terlalu sulit. Alat tes yang baik harus dapat dipertanggungjawabkan dari segi kelayakan (appropriateness), kesahihan (validity), keajegan (reliability), ketertafsiran (interpretability), dan kebergunaan (usability) (Suwandi, 2009).

Dari latar belakang di atas, maka diperlukan penelitian pengembangan penilaian yang mampu melatih Higher Order Thinking Skills siswa. Pengembangan penilaian ini digunakan untuk mengukur kognitif produk Higher Order Thinking Skills yang dilakukan. Namun sebelum pengembangan penilaian HOTS ini digunakan maka perlu diadakannya uji kelayakan instrumen penilaian HOTS pada materi ekosistem. Tujuan penelitian ini untuk mengetahui kelayakan insrumen penilaian HOTS pada materi ekosistem pada siswa SMA di Surakarta.

\section{MetodePenelitian}

JenisPenelitian

Penelitian ini menggunakan model penelitian dan pengembangan (Research \& Development) yang mengacu pada Borg \& Gall (1983).

Waktu dan Tempat Penelitian

Penelitian pengembangan penilaian dilakukan di lima Sekolah Menengah Atas di Surakarta, Jawa Tengah, yaitu SMA Negeri 2, SMA Negeri 3 SMA Negeri 4, SMA Negeri 6, dan SMA Negeri 7 Surakarta. Sampel yang digunakan adalah siswa kelas $\mathrm{X}$ dan XI yang telah mempelajari materi ekosistem semester genap..

Prosedur
Penelitian ini menggunakan model penelitian dan pengembangan (Research \& Development) yang mengacu pada Borg \& Gall (1983). Dengan langkah sebagai berikut:

Penelitian pendahuluan, dilakukan untuk mencari permasalahan yang akan diselesaikan melalui produk pengembangan. Langkah awal dilakukan dengan mengidentifikasi pencapaian delapan Standar Nasional Pendidikan; wawancara pada guru terkait proses pembelajaran; menganalisis hasil butir soal ulangan harian, Ujian Tengah Semester (UTS), Ujian Akhir Semester (UAS), Ujian Nasional (UN), serta analisis banksoal yang digunakan guru untuk mengetahui persentase penggunaan tingkat Taksonomi Bloom dalam soal; studi pustaka dilakukan dengan membaca buku dan jurnal penunjang.

Desain Perencanaan, membuat perencanaan produk awal (prototype) soal. Langkah yang dilakukan sebagai berikut:

a. Identifikasi SK dan KD serta jenis materi yang akan dikembangkan untuk menetapkan indikator pembelajaran.

b. Menentukan indikator berpikir tingkat tinggi yang diadaptasi dari Taksonomi Bloom meliputi C4 (menganalisis), C5 (mengevaluasi), dan C6 (mencipta).

c. Membuat kisi-kisi soal. Kisi-kisi soal yang dibuat merupakan indikator kognitif berdasarkan Taksonomi Bloom.

d. Membuat matrik soal. Matrik soal yang dibuat merupakan perpaduan antara dimensi proses kognitif berpikir tingkat tinggi dengan dimensi pengetahuan yang meliputi pengetahuan faktual, konseptual, prosedural, serta metakognitif dari Anderson \& Krathwohl (2001).

Produk awal pengembangan dilakukan proses pengembangan instrumen penilaian keterampilan berpikir tingkat tinggi pada materi ekosistem, yang terdapat kompetensi, materi, uraian tugas, panduan penggunaan, rubrik penilaian, panduan penilaian, lembar penilaian Higher Order Thinking Skills, dan contoh penilaian.Mengembangkan produk awal soal pilihan ganda dan uraian menggunakan kasus permasalahan seputar ekosistem dan lingkungan berjumlah kurang lebih 25 dan 38 
soal.Penyusunan instrumen validasi soal. Instrumen validasi soal yang digunakaan adalah angket yang nantinya diberikan kepada ahli materi, ahli instrument evaluasi, guru senior, dan siswa.

Validasi Produk mengacu pada langkah-langkah validasi dalam Borg \& Gall (1983) sebagai berikut :

a. Validasi Soal kepada Ahli dan Guru Senior, ahli yang digunakan dalam penelitian adalah orang yang memiliki bidang ilmu linear dengan tujuan pengembangan produk yakni Prof. Dr. Maridi, M.Pd yang merupakan dosen bidang ilmu lingkungan di Program Studi Pendidikan Sains Pascasarjana Universitas Sebelas Maret. Ahli penilaian yang dilibatkan adalah dosen pengampu mata kuliah penilaian dan evaluasi pembelajaran yakti Dr. Nonoh Siti Aminah, M.Pd yang merupakan dosen bidang ilmu Penilaian Evaluasi Pendidikan program studi fisika FKIP Universitas Sebelas Maret. Guru senior yang dilibatkan adalah guru yang berpengalaman mengajar di Sekolah Menengah Atas.Data kelayakan soal diukur menggunakan kriteria kelayakan soal. Data yang diperoleh kemudian dianalisis, jika hasil validasi dari para validator belum layak maka dilakukan revisi terhadap produk sesuai saran validator, selanjutnya dilakukan validasi kembali ke validator.

b. Validasi Soal Kepada Pengguna,terdapat proses validasi dalam evaluasi formatif (Borg \& Gall, 1983). Proses validasi yang dimaksud adalah uji coba terbatas serta uji coba lapangan.Uji coba terbatas meliputi uji coba kelompok kecil yang di ambil secara random untuk menilai kelayakan produk, menilai konsep, keterbacaan soal, dan kemudahan soal. Uji coba kecil dilakasanakn di SMAN 2 Karanganyardengan 20 siswa mengerjakan tes ekosistem dan 18 siswa mengerjakan tes Ekosistem.Uji coba lapangan dilakukan ke beberapa siswa (tidak termasuk siswa yang diambil pada uji coba terbatas). Sampel uji coba lapangan ialah siswa dengan populasi 28-30 anak di masingmasing sekolah di Surakarta yang telah ditentukan. Tujuan uji coba lapangan adalah menentukan apakah produk yang dihasilkan memiliki kelayakan menjadi soal yang baik, valid, reliabel, dan praktis serta siap disebarluaskan.

c. Uji Coba Produk Pengembangan, bertujuan untuk mengumpulkan data tentang kelayakan soal yang digunakan,berdasarkan data yang diperoleh dari ahli validator meliputi aspek konten, konstruk dan bahasa. Subjek uji coba adalah beberapa siswa kelas $\mathrm{X}$ pada uji coba terbatas dan XI pada uji coba lapangan yang diperoleh secara random.Uji coba terbatas meliputi uji coba kelompok kecil. Tujuan uji coba kelompok adalah memperoleh bukti-bukti empirik tentang kelayakan produk awal secara terbatas.Subjek uji coba terbatas adalah siswa kelas X.Desain Uji Coba dengan kelas diberikan soal. Materi soal dan konstruk soal yang sesuai.Hasil diuji untuk mengetahui respon siswa terhadap bentuk instrumen penilaian dalam mengukur keterampilan berpikir tingkat tinggi siswa.

d. Uji Coba Lapangan tujuan menentukan apakah produk yang dihasilkan memiliki kelayakan menjadi soal yang baik, valid, reliabel, serta siap disebarluaskan.

\section{TeknikAnalisisData}

Teknik analisis data dimulai dari tahap analisis kebutuhan, validasi ahli dan guru senior, dan uji coba terbatas. Data tentang analisis kebutuhan dianalisis dengan teknik analisis deskriptif yaitu dengan mendiskripsikan dan memaknai data dari masing-masing komponen yang dievaluasi. Data yang terkumpul dianalisis dengan teknik deskriptif yaitu dengan menyajikan hasil perhitungan statistik deskriptif berupa tabel frekuensi dan persentase yang didapat dari hasil penelitian. Hasil dari analisis digunakan untuk mempertimbangkan kebutuhan pengembangan. 
Data Validasi Ahli dan Guru Senior, data penilaian ahli dan guru senior terhadap soal dianalisis dengan teknik deskriptif dengan mengunakan persentase (Purwanto, 2010). Analisis data dilakukan dengan cara menghitung skor yang dicapai dari seluruh aspek yang dinilai kemudian menghitungnya dengan rumus sebagai berikut:

$$
N=k_{x}{ }_{100 \%}
$$

\section{Nk}

Keterangan:

$\mathrm{N} \quad$ : persentase kelayakan aspek

$\mathrm{k} \quad$ : skor hasil pengumpulan data

$\mathrm{Nk} \quad$ : skor maksimal (skor kriteria tertinggi $\mathrm{x}$ jumlah aspek $\mathrm{x}$ jumlah validator).

Sumber: Sudjana (2009)

Data penilaian terhadap soal oleh guru pengguna dan siswa pada uji coba terbatas dianalisis dengan teknik deskriptif menggunakan persentase (Purwanto, 2010). Perhitungan data yang dilakukan sama dengan perhitungan data validasi ahli dan guru senior.

Pada uji coba lapangan terdapat dua jenis data, yakni data kualitatif dan data kuantitatif. Data kualitatif diperoleh dari data kepraktisan soal ( suatu instrumen yang dikatakan baik atau tidak baik), data tersebut diperoleh dari guru pengguna. Data kepraktisan soal dianalisis dengan teknik deskriptif presentase (Purwanto, 2010). Data kuantitatif diperoleh dari pengujian soal yang meliputi uji validitas, reliabilitas, daya beda, tingkat kesukaran soal. Instrumen akan menghasilkan data dikotomus yang kemudian dianalisis dengan program QUEST menurut model Rasch (Rasch Model atau RM) guna mengetahui validitas dan reliabilitas.

\section{HasilPenelitiandanPembahasan}

Karakteristik Instrumen Penilaian Higher Order Thinking Skills

Hasil Studi Pendahuluan

Penelitian pendahuluan merupakan analisis kebutuhan yang dilakukan di sekolah untuk mencari permasalahan yang akan diselesaikan melalui produk pengembangan. Permasalahan yang ada di sekolah diidentifikasikan melalui wawancara dan observasi. Identifikasi dilakukan dengan melihat tingkat pemenuhan delapan Standar
Nasional Pendidikan (SNP) di sekolah yang meliputi standar isi, standar proses, standar kompetensi lulusan, standar pendidik dan tenaga pendidik, standar sarana dan prasarana, serta standar penilaian. Dari pemetaan pendidikan melalui pemenuhan delapan (8) Standar Nasional Pendidikan (NSP) pada subyek menggambarkan bahwa capaian pemenuhan standar proses (standar 2) dan standar penilaian (standar 8) menunjukkan adanya gap yang terbesar antara skor ideal dan skor riil, yaitu sebesar 3,70\%. Hal ini terjadi karena ketercapaian kompetensi pembelajaran di SMA Surakarta melalui aspek kognitif belum dapat meningkatkan Higher Order Thinking Skills siswa (Sajidan., et.al, 2013). Analisis berikutnya ialah bank soal, yang meliputi soal ujian nasional, ujian akhir sekolah, ujian sekolah, ulangan harian dan dari buku paket yang siswa dan guru gunakan. Analisisnya dengan meninjau konten soalnya, yaitu tingkat kesulitan yang lebih tinggi (Higher Order Thinking Skills).

Tabel 1. Presentase Lower Order Thinking Skills dan Higher Order Thinking SkillsTingkat Kognitif SMA di Surakarta Materi Ekosistem

\begin{tabular}{rccccc}
\hline Sekolah & \multicolumn{3}{c}{ Ekosistem } & \\
\cline { 2 - 3 } & $\begin{array}{c}\text { Jumlah } \\
\text { Butir Soal }\end{array}$ & ELOTS & $\%$ & EHOTS & $\%$ \\
\hline SMA 2 & 60 & 52 & 86,6 & 7 & 8,3 \\
SMA 3 & 68 & 58 & 85,2 & 6 & 14,7 \\
SMA 4 & 58 & 54 & 93,1 & 6 & 6,8 \\
SMA 6 & 81 & 75 & 92,5 & 5 & 7,4 \\
SMA 7 & 83 & 79 & 95,18 & 6 & 4,81 \\
\hline Presentase & & & 90,5 & & 8,4 \\
\hline
\end{tabular}

Lower Order Thinking Skills lebih besar dibandingHigher Order Thinking Skills di lima sekolah tersebut persentase Lower Order

Thinking Skills secarakesuluruhan pada lima sekolah dengan menganalisis bank soal sebesar $90,5 \%$ danhanya sebesar $8,4 \%$ persentaseHigher Order Thinking Skillspadamateriekosistem, Berdasarkan hasil analisis bank soal tersebut, salah satu cara yang dapat dilakukan untuk meningkatkan berpikir tingkat tinggi siswa pada materi ekosistem tersebut adalah dengan mengembangkan instrumen penilaian yang mampu melatih siswa untuk memberdayakan keterampilan berpikir tingkat tinggi(Higher Order Thinking Skills).

\section{Analisis Hasil Validasi Ahli dan Guru Senior}

Data hasil validasi ahli dan guru senior dianalasis untuk menilai kelayakan instrumen 
penilaian hasil pengembangan. Analisis hasil penilaian ahli materi ditunjukan pada Gambar1.

$\begin{array}{cl}\text { Gambar 1. Persentase Indikator Penilaian } \\ & \text { Aspek Materi Instrumen } \\ & \text { Penilaian Higher Order Thinking } \\ & \text { Skills Materi Ekosistem }\end{array}$

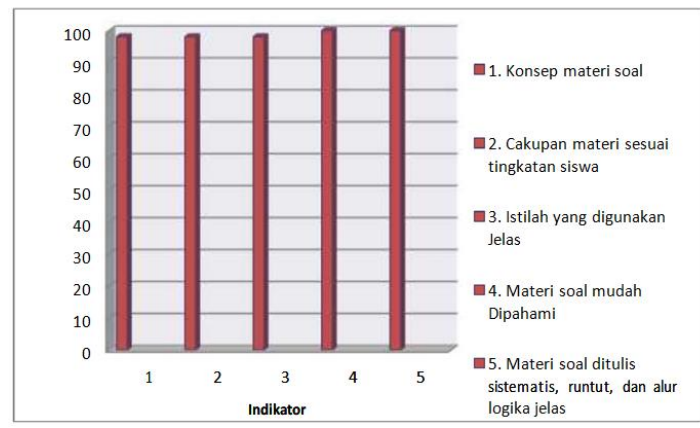

Analisis terhadap gambar 1 menunjukan tidak ada kesalahan konsep dalam materi soal, cakupan materi sesuai dengan tingkatan siswa, istilah yang digunakan dalam soal mudah dipahami siswa, materi soal mudah dipahami siswa, materi soal ditulis sistematis, runtut, serta alur logika jelas. Kesimpulan yang diperoleh adalah instrumen penilaian memiliki validitas isi yang sangat baik.Validitas isi (content validity) adalah validitas yang mempertanyakan bagaiamana kesesuaian butir soal dalam tes dengan deskripsi bahan yang diajarkan (materi) (Munthe, 2012). Validitas instrumen penilaian meliputi validitas isi dan validitas konstruk. Validitas konstruk instrumen penilaian dinilai oleh ahli instrumen evaluasi.

Gambar 2. Persentase Indikator Penilaian Aspek Konstruk Instrumen Penilaian Higher Order Thinking Skills Materi Ekosistem.

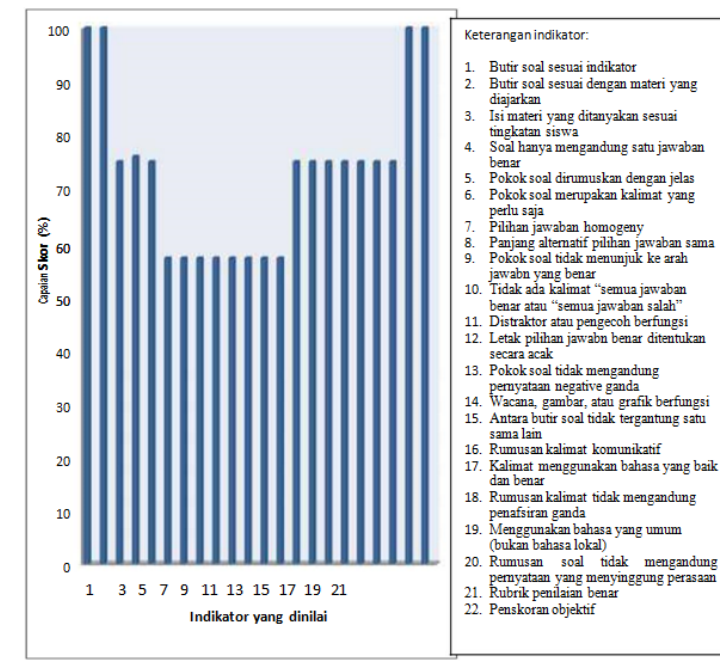

Analisis terhadap gambar 2 menunjukan instrument yang dikembangkan sesuai dengan indicator pembelajaran, butir soal yang dikembangkan sesuai dengan materi yang diajarkan, isi materi sesuai tingkatan siswa,soalhanyamengandungsatujawaban benar, dirumuskan dengan jelas, pokoksoal merupakan kalimat yang diperlukan saja, pilihan jawaban homogeny, panjang alternatif jawaban sama, pokok soal tidak menunjuk kearah jawaban benar, tidak ada kalimat "semua jawaban benar" atau "semua jawaban salah", distraktor atau pengecoh berfungsi, letak pilihan jawaban ditentukan secara acak, pokok soal tidak mengandung pernyataan negatif ganda, wacana,gambarberfungsi,antarabutirsoaltidakter gantungsatusamalain, rumusan kalimat komunikatif, kalimat menggunakan bahasa yang baik dan benar rumusan kalimat tidak menimbulkan penafsiran ganda, menggunakan bahasa yang umum (bukan bahasa lokal), rumusan soal tidak menyinggung perasaan, rubrik penilaian soal benar, serta penskroran objektif. Kesimpulan yang diperoleh adalah instrument penilaian yang memiliki validitas konstruk yang baik.

Arikunto (2007) menyebutkan sebuah tes dikatakan memiliki validitas konstruksi apabila butir-butir soal yang membangun tes tersebut mengukur setiap aspek berpikir seperti yang disebutkan dalam tujuan instruksional khusus atau sesuai dengan aspek berpikir yang menjadi tujuan instruksi khusus. Indikator Higher Order Thinking Skills yang digunakan diadaptasi dari Anderson dan Kratwohl (2001) meliputi kemampuan menganalisis, mengevaluasi, dan menciptakan. Pencocokan validitas konstruk dilakukan dengan memasangkan setiap butir soal dengan aspek indikator Higher Order Thinking Skills.

Validasi instrumen penilaian pengembangan dilanjutkan kepada guru senior untuk dinilai kelayakan instrumen tersebut sebelum penerapan di sekolah. Hasil penilaian kelayakan instrumen penilaian oleh guru senior disajikan pada Gambar 3.

Gambar3. Persentase Penilaian Indikator Kelayakan Instrumen Ahli Guru Senior 1 Materi Ekosistem

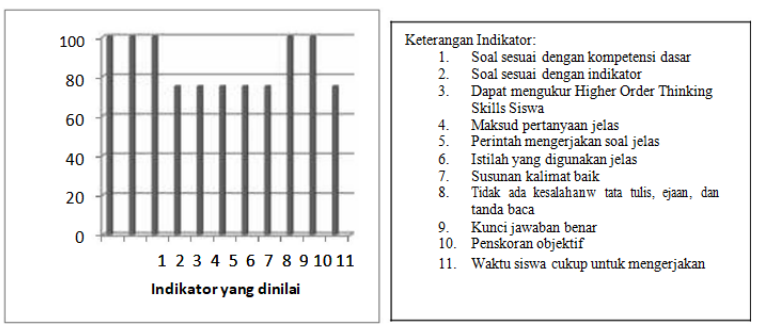


Gambar 4. Persentase Penilaian Indikator Kelayakan Instrumen Ahli Guru SeniorMateri Ekosistem.

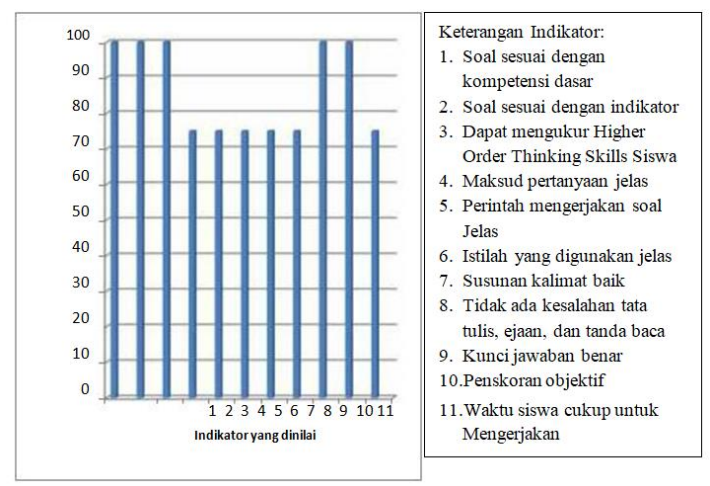

Analisis terhadap Gambar 4menunjukan instrumen penilaian hasil pengembangan sesuai dengan kompetensi dasar yang ditetapkan, soal sesuai dengan indikator, soal dapat digunakan untuk mengukur Higher OrderThinking Skills siswa, maksud pertanyaan pada soal jelas, perintah mengerjakan soal jelas, istilah yang digunakan pada soal jelas, susunan kalimat pada soal cukup baik, penulisan soal cukup baik, kunci jawaban benar, penskoran objektif, dan manajemen waktu pada soal cukup baik sehingga waktu siswa cukup untuk mengerjakan soal tersebut. Kesimpulan hasil validasi instrumen penilaian kepada ahli materi, ahli instrument evaluasi, dan guru senior adalah instrumen penilaian Higher Order Thinking Skills memiliki validitas isi dan validitas konstruk yang sangat baik dan baik serta layak diterapkan kepada pengguna sekolah.

\section{Analisis Uji Coba Kelompok Kecil}

Uji coba kecil materi Ekosistem dengan 40 butir soal terdapat 22 butir sebesar 55\% yang diterima, 18 butir soal sebesar $45 \%$ direvisi. Dari hasil analisis tersebut butir soal dipengaruhi oleh tingkat kesukaran, daya beda dan efektivitas distraktor dari butir soal yang dikerjakan oleh siswa. (lihat lampiran data analisis tingkat kesukaran, daya beda dan efektivitas distraktor). Kemudian pada uji coba kelompok kecil ini diketahui seberapa mudah siswamemahamimateripadainstrumenpenilaiani ni.Hasilrespondiketahui berapabesaraspekgunamelihatketerbacaandanta nggapansiswamengenai instrument penilaian Higher Order Thinking Skills.

Gambar 4.Hasil Respon Siswa

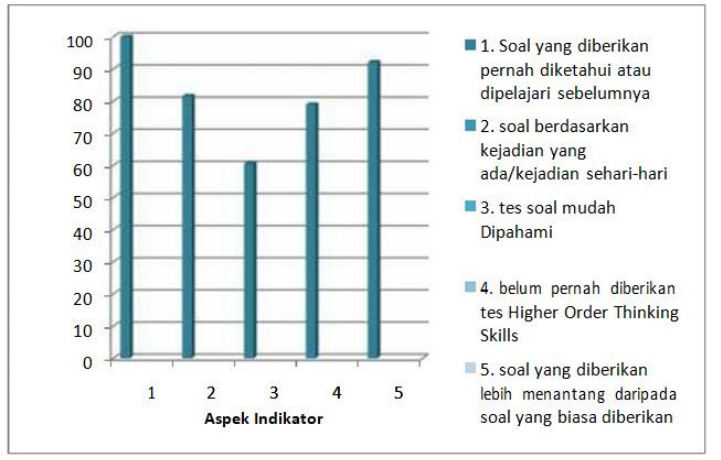

Berdasarkan hasil respon siswa $100 \%$ tes soal yang diberikan pernah diketahui atau dipelajari sebelumnya, $81,58 \%$ tes soal berdasarkan kejadian yang ada/kejadian seharihari, $60,55 \%$ tes soal mudah dipahami, 78,95\% belum pernah diberikan tes Higher Order Thinking Skills, dan $92,11 \%$ tes soal yang diberikan lebih menantang daripada soal yang biasa diberikan. Hasil di atas menunjukkan bahwa tes soal siap diujikan di uji coba lapangan.

\section{Analisis Hasil Uji Coba Lapangan}

Data pengujian lapangan digunakan untuk menentukan apakah produk yang dihasilkan memiliki kelayakan menjadi soal yang valid, reliabel, dan praktis. Pengujian Validitas butir soal ditentukan dengan menggunakan program Quest. Item soal di atas dikatakan valid apabila mempunyai dukungan yang besar terhadap skor total (Arikunto, 2007).

Berdasarkan hasil pengujian insrumen Higher Order Thinking Skills materi ekosistem dari 25 soal pilihan ganda maupun essay yaitu $100 \%$ valid dengan interpretasi $84 \%$ sangat tinggi (21 butir), $4 \%$ tinggi ( 1 butir), cukup $4 \%$ (1 butir), 8\% rendah (2 butir). Pada materi ekosistem memiliki tingkat kesukaran dengan proporsi $2,20 \%$ sukar dan $97,89 \%$ sedang (pilihan ganda), 33,33\% sukar dan 66,66\% sedang (essay), memiliki daya beda dengan proporsi $83,15 \%$ cukup dan $16,84 \%$ baik (pilihan ganda), $43,33 \%$ cukup, $40 \%$ baik dan $10 \%$ sangat baik (essay).

Reliabilitas instrumen penilaian Higher Order Thinking Skills hasil pengembangan pada materi ekosistem memiliki rata-rata sebesar 0,835 , artinya soal tersebut memiliki kehandalan yang sangat tinggi. Pada essay materi ekosistem memiliki rata-rata sebesar 0,6, artinya soal tersebut kehandalannya tinggi. Hasil Uji lapangan diperoleh hasil bahwa instrumen penilaian pengembangan termasuk 
kategori soal yang baik. Instrumen penilaian pada materi ekosistem memiliki validitas dan reabilitas dengan interpretasi rata-rata sangat tinggi, minimal rendah pada materi ekosistem. Pada materi ekosistem memiliki tingkat kesukaran dengan proporsi $2,20 \%$ sukar dan 97,89\% sedang (pilihan ganda), 33,33\% sukar dan $66,66 \%$ sedang (essay), memiliki daya beda dengan proporsi $83,15 \%$ cukup dan $16,84 \%$ baik (pilihan ganda), 43,33\% cukup, $40 \%$ baik dan $10 \%$ sangat baik (essay).

Hasil validasi perangkat instrumen penilaian dimasing-masing ahli validator ialah memiliki validasi isi dan konsruk yang baik dan layak untuk diterapkan di sekolah tentunya setelah dilakukan revisi, dimana revisi yang meliputi memperbaiki konsep yang masih salah, memperbaiki kesesuian dengan konsep taksonomi Bloom, memperbaiki penggunaan istilah kata yang masih banyak kesalahan, serta alokasi waktu. Revisi tersebut guna untuk memperbaiki instrumen penilaian yang akan digunakan pada uji kelompok kecil.

Uji kelompok kecil dilakukan pada 38 siswa yang dipilih secara random. 38 siswa dibagi menjadi dua untuk mengerjakan soal Higher Order Thinking Skills materi ekosistem. Hasil uji coba kelompok kecil dilihat dari butir soal yang dikerjakan terdapat beberapa butir soal yang perlu revisi dan beberapa butir soal diterima setelah diolah data secara kuantitatif. Adapun tanggapan yang diberikan oleh siswa pada uji coba kecil yaitu memperbaiki kesalahan tata tulis, kalimat dan gambar yang kurang jelas. Setelah direvisi maka dilakukan uji coba lapangan di lima sekolah di Surakarta. Uji coba dilakukan pada siswa kelas XI yang sebelumnya telah mempelajari materi ekosistem sewaktu di kelas X. Subjek penelitian dilakukan di lima sekolah di Surakarta. Hasil coba ini dianalisis untuk mendapatkan validitas butir soal, reliabilitas, daya beda, dan tingkat kesukaran soal. Hasil dari uji coba lapangan mendapatkan kesimpulan bahwa instrumen penilaian Higher Order Thinking Skills memiliki validitas dan reabilitas dengan interpretasi rata-rata sangat tinggi, minimal rendah pada materi ekosistem, dan minimal cukup pada materi ingkungan.

Berdasarkan hasil tersebut, instrumen penilaian Higher Order Thinking Skills dinilai sangat baik dan layak untuk diterapkan di sekolah karena butir soal telah memenuhi syarat dalam validitas isi, konstruk dan bahasa yang baik yang diharapkan mampu meningkatkan kemamuan berpikir tingkat tinggi siswa.. Hal ini didukung dengan penelitian oleh Lissa (2012) yaitu mengembangkan insrumen penilaian keterampian Higher Order Thinking Skills pada materi sistem respirasi dan ekskresi. Hasil penelitian Lissa (2012) mengungkapkan bahwa penerapan instrumen penilaian Higher Order Thinking Skills yang dirancang sedemikian rupa dapat memberikan pengaruh yang positif atau signifikan terhadap hasil belajar.Berdasarkan hasil uji validitas isi serta analisis butir tes yaitu tingkat kesukaran, daya beda dan efektifitas distraktor pada penyusunan instrumen tes kemampuan berpikir tingkat tinggi diperoleh hasil bahwa indikator indikator yang dikembangkan dalam bentuk item tes telah memenuhi syarat sebagai instrumen tes yang baik.

Instrumen penilaian Higher Order Thinking Skills ini sesuai dengan yang diisyaratkan pemerintah pendidikan, yaitu SSP. Instrumen ini memuat perangkat pembelajaran yang mendidik yang komprehensif, sistematis dan solid yang mencakup kisi-kisi lembar penilaian dan lembar penilaian (Hartati et al, 2009). Instrumen ini dibuat disesuaikan dengan materi dan karakteristik peserta didik. Berdasarkan Peraturan Menteri Pendidikan Nasional Nomor 41 Tahun 2007 diisyaratkan bahwa dalam perencanaan proses pembelajaran meliputi beberapa macam perangkat yang dapat dikemas dalam Subject Spesific Pedagogy (SSP). Ini juga didukung oleh ahli yang menyatakan bahwa proses pengukuran efektivitas proses penilaian dapat dilakukan melalui pemilihan pendekatan, strategi dan model pembelajaran yang efektif (Ong and Borich, 2006). Salah satu pendekatan yang relevan dengan pendekatan saintifik dalam pembelajaran dan pengembangan subject specific pedagogy/SSP (Ogawa, 2001; Sniveley and Corsiglia, 2001; Hodson, 2009).

\section{Simpulan}

Disimpulkan dari hasil penelitian pengembangan instrumen penilaian Higher Order Thinking Skills pada materi ekosistem adalah sebagai berikut:

1. Karakteristik penilaian yang mengukur Higher Order Thinking Skills siswa SMA yaitu instrumen penilaian dengan indikator yang memiliki tingkatan seperti menganalisis, mengevaluasi dan mencipta (Taksonomi Bloom yang terevisi) dengan 
soal berbentuk pilihan ganda dan essay berdasarkan kasus.

2. Instrumen penilaian Higher Order Thinking Skills pada materi ekosistem dinilai layak dan dapat diterapkan di sekolah.

\section{DaftarPustaka}

Aiken, Lewis R. (1994).Psychological Testingand Assessment,(EightEdition). USA: Addison Wesley Longman.

Anastasi, Anne and Urbina, Susana. (1997). Psichological Testing. (Seventh Edition). New Jersey: Prentice-Hall,Inc

Anderson, W. L \& Krathwohl, R, D. (2001). A Taxonomy for Learning Teaching and Assesing A Revision of Bloom's Taxonomy of Educational Objectives.

Aprianto. (2008). Implementasi Sistem Sistem Manajemen Mutu ISO 9001: 2008 Berdasarkan Pada 8 (delapan) prinsip manajemen mutupada SMK Negeri 13 Bandung. Universitas Tekhnilogi Bandung: Bandung

Arifanni, Kanti. 2013. Pengembangan Subject Spesific Pedagogy (SSp) Matematika Pada Materi Bangun Prisma Berbasis Tahap Berpikir Van Hiele Dan Teori Bruner Untuk Peserta Didik SMP/MTs Kelas VIII. Universitas Islam Negeri Sunan Kali Jaga Yogyakarta: Yogyakarta

Arikunto, Suharsimi. (2007). Dasar-Dasar Evaluasi Pendidikan. Jakarta : Bumi Aksara

Basuki, Ismet, \& Hariyanto. (2012). Assesmen Penelitian. Bandung: PT Remaja Rosdakarya Offset

Bloom. (1964).Taxonomy of Educational Objectives: Handbook I: Cognitive Domain Butkowski, Jean. 1994. Improving Student Higher Order Thinking Skills in Mathematics. Tesis, Educational Resources Information Center

Borg and Gall. (1983). Educational Research, An Introduction (4th $E d$ ). Newyork and London. Longman Inc.Boston: Allyn and Bacon.

BSNP. (2007). Peraturan Menteri Pendidikan Nasional Republik Indonesia No 42 Tahun 2007 tentang Standar Proses. Jakarta: BSNP
Budiman, Agus. (2014). Pengembangan Instrumen Asesmen Higher Order Thinking Skills (HOTS) Pada Mata Pelajaran Matematika SMP Kelas VIIISemester 1. Universitas Negeri Yogyakarta: Yogyakarta. Jurnal Riset Pendidikan Matematika, Volume 1, No 2, Novermber 2014

Campbell, Neil A., Reece, Jane B., \& Mitchell, Lawrence G. (2004). Biology Edisi Kelima Jilid 3. Erlangga : Jakarta

Gronlund, M. S and Linn, Joyce. (1995). Measurement And Assesment In Teaching. Prentice-Hall, Pearson Education Upper Saddle River, New Jersey

Heong, Y. M, Widad B. O,Jailani B. M. Y, Tee T.K, Razali B. H,and Mimi M.B.M.(2011). TheLevelof Marzano Higher Order ThinkingSkills among Technical Education Students. International Journal of Social Science and Humanity, Vol. 1, No. 2.

Hosnan. (2014). Pendekatan Saintifik dan Kontekstual Dalam Pembelajaran Abad 21. Ghalia Indonesia: Bogor

Kartowagiran, Badrun. (2011). Pengembangan Instrumen Asesmen Pembelajaran DiSekolahBertarafInternasional.Univer sitasNegeriYogyakarta: Yogyakarta

Kemendikbud. (2013) . Permendikbud No. 81A tentang Implementasi Kurikulum. Jakarta: Kementerian Pendidikan dan Kebudayaan

Kind, V. (2009) 'Pedagogical content knowledge in science education : potentialand perspectivesforprogress.',Studiesin science education., 45 (2). pp. 169-204.

King, JF; Goodson, Ludwika, dan Rohani, Faranak, (2010). Higher Order Thinkin Skills, Definition, Teaching Strategis, Assesment. A Publication of The Educational Services Program. www.Cala.fsu.edu.

Krathwohl, Bloom \& Masia. (1964). The Taxonomy of Educational Objectives:Handbook II Krathwohl, D. R.2002. A revision of Bloom's Taxonomy: an overview - Theory Into Practice,College of Education, The Ohio State University Learning Domains or Bloom's Taxonomy: The Three Types of Learning, tersedia di www.nwlink.com/ donclark/hrd/bloom .html 
Lewis, A., \& Smith, D. (1993). Defining Higher Order Thingking. Theory Into Practice, XXXII (3), 131-137

Lewy.(2009).PengembanganSoalUntukMenguk urKemampuanBerpikir Tingkat Tinggi Pokok Bahasan Barisan dan Deret BIlangan di KElas IX AkselerasiSMP

Xaverius

Palembang.Jurnal

Matematika, Volume3

No.2,Desember2009.UniversitasSriwija ya: Palembang

Lissa. (2012). Pengembangan Instrumen Penilaian Keterampilan Berpikir Tingkat Tinggi Materi Sistem Respirasi dan Ekskresi. Universitas Negeri Semarang: Semarang

Madhuri,G.V.,Kantamreddi,V.S.S.N.,danGoteti ,L.N.S.P.(2012).Promoting Higher Order Thinking Skills using inquirybased learning. European Journal of Engineering Education. Vol. 37, No. 2, 117-123

Mardapi, Djemari. (2008). Teknik Penyusunan Instrumen dan Nontes. Yogyakarta: Mitra Cendikia Offset

Munthe, Bermawi. (2012). Desain Pembelajaran. Yogyakarta: Pustaka Insan Madani

Nitko, Anthony J. (1996). Educational Assessment of Students, Second edition. Ohio: Merrill an imprint of Prentice Hall Englewood Cliffs.

Nofiana, Mufida. (2013). Pengembangan Instrumen Evalusi Two-Tier Multiple Choice Question Untuk Mengukur Keterampilan Berpikir Tingkat Tinggi Pada Materi Kingdom Plantae. Universitas Sebelas Maret: Surakarta

Ogawa, M. (1995). Science Education In AMultiscience Perspective. Science Education, 79, 593- 593.

Ong, A \& Borich.G.D. 2006. Teaching Strategies That Promote

Thinking:Modeland

CuriculumApproaches.Singapore:Mc Graw Hill.

Partnership for 21st century Skill. (2009). 21st CenturySkills

Map.http://science.nsta.org/ps/

Final21stCenturyMapScience.pdf. Diakses 1 maret 2015

Peraturan Menteri Pendidikan Nasional Republik Indonesia. (2007). PeraturanMenteri Pendidikan Nasional Republik Indonesia Nomor 20 Tahun
2007Tentang Standar Penilaian Pendidikan untuk Satuan Pendidikan Dasar danMenengah. Jakarta : Depdiknas

Poerwanti,E.(2001).EvaluasiPembelajaran,Mo dulAktaMengajar.UMM. Press.

Purwanto. (2010). Evaluasi Hasil Belajar. Yogyakarta: Pustaka Pelajar

Puspendik. (2011). Instrumen Penilaian Hasil Belajar Matematika SMP:Belajar dari PISA dan TIMMS. Jakarta: Puspendik, Balitbang Depdiknas.

Rahayu. (2008). Pengembangan Instrumen Penelitian Dalam PendidikanMatematika Realistik Indonesia (PMRI) di SMPN 17 Palembang. Jurnal Pendidikan Matematika, Vol 2, No. 2, Juli Desember 2008.

Reynold, C.R., Livingston, R. B., \& Willson, V. (2010). Measurement and Assesment in Education. Pearson Eucation, Inc., Upper Saddle River, New Jersey 07458. Pearson.

Rochmah, Tyagita F. (2013). Penerapan Model Pembelajaran Inkuiri Untuk Meningkatkan Hasil Belajar Biologi Siswa Kelas X-G MAN Malang 1. Universitas Negeri Malang: Malang

Rofiah, E, Nonoh S. A, dan Elvin Y.E. (2013). Penyusunan Instrumen Tes Kemampuan Berfikir Tingkat Tinggi Fisika Pada Siswa SMP. Jurnal Pendidikan Fisika. ISSN: 2338-0691. Surakarta: FKIP Fisika UNS.

Sajidan, Sugiharto B. \& Prasetyani, N.M. (2013). Penerapan Dan Pengembangan Mutu Pendidikan Melalui Lesson Studi Pada MataPelajaran Biologi Berbasis Pemetaan Ketuntasan UN Biologi, Laporan Hibah Guru Besar. LPPM : UNS

Shchur, N.M., 2014. Pre-Service Biology Teacher Preparation in the Usa And Ukraine: Comparative Study of Professional Education Training. American Journal of Educational Research, 2014, Vol. 2, No. 5, 278-282

Slameto (2003). Belajar dan Faktor-faktor Yang Mempengaruhinya. Jakarta: PT. Rineka Cipta

Subali, Bambang. (2010). Penilaian, Evaluasi dan Remediasi Pembelajaran Biologi. UNY: Yogyakarta 
Sudjana, Nana. (2009). Penilain Hasil Proses Belajar Mengajar. Bandung:Remaja Rosdakarya

Sudjana,Nana.(2010).PenilaianHasilProsesBel ajarMengajar.Bandung:Remaja Rosdakarya

Sukiman. 2012. Pengembangan Media Pembelajaran. Yogyakarta: Pendajogja

Sungarimbun, Masri dan Sofian Effendi.(2008). Metode Penelitian Survei. Jakarta: LP3ES

Suparman,Atwi. (2012). Desain Instruksional Modern. Bandung: Erlangga

Surapranata, S., (2005). Analisis, Validitas, Reliabilitas dan Interpretasi Hasil Tes. Implementasi kurikulum 2004. Bandung: Remaja Rosdakarya Offset

Susongko, Purwo. (2010). Perbandingan Keefektifan Bentuk Tes Uraian Dan Testlet Dengan Penerapan Graded Response Model (GRM). UPS : Tegal

Suwandi, Sarwiji. (2009). Model Asesmen Dalam Pembelajaran. Mata Padi Presindo: Surakarta

Tatat Hartati, Yahya Sudarya, Tatang Suratno, dan Effy Mulyasari. (2009). Pedagogic produktif dan subject specific pedagogy. Bandung: UPI

Wardana,N.(2010).PengaruhModelPembelajar anBerbasisMasalahdan Ketahan malangan Terhadap Kemampuan Berpikir Tingkat Tinggi danPemahama KonsepFisika.http://jurnal.pdii.lipi.go.i d/admin/jurnal/621016251635_18584543.pdf 